\title{
The impact of charitable subsidies on religious giving and attendance: Evidence from panel data
}

\author{
Barış K. Yörük* \\ University at Albany, SUNY ${ }^{\dagger}$
}

November 24, 2011

\begin{abstract}
In the United States, charitable contributions can be deducted from taxable income making the price of giving inversely related to the marginal tax rate. The existing literature documents that charitable giving is very responsive to tax subsidies, but often ignores the spillover effects of such policies. This paper investigates the spillover effects of charitable subsidies on religious participation using a newly available individual-level panel data. Understanding these spillover effects may be quite important, given the existing literature that links religiosity to several economically important social behaviors. The results show that religious giving and participation are complements. Increasing the price of religious giving decreases not only religious contributions but also religious attendance. The implied cross-price elasticity of religious participation with respect to the after-tax price of giving is -0.27 . Furthermore, a $1 \%$ increase in the amount of religious contributions is associated with a $0.4 \%$ increase in religious attendance. These results are robust under several different specifications and highlight the positive externalities created by charitable subsidies. They also have important implications for testing the validity of existing economic models of religious participation and giving.
\end{abstract}

Keywords: charitable subsidy, religious giving, religious participation

JEL classification: H24, H31, L38

\footnotetext{
${ }^{*}$ I thank session participants at EEA Meetings (2011), Daniel Hungerman, and Michael Jerison for their helpful comments. All errors remain mine.

${ }^{\dagger}$ Department of Economics, University at Albany, SUNY, 1400 Washington Ave., Albany, NY 12222. Tel: (518) 442-3175. Fax: (518) 442-4736. E-mail: byoruk@albany.edu.
} 


\section{Introduction}

In the United States and several other countries, charitable contributions are tax deductible. This policy makes a charitable donation less costly for those who itemize deductions in their federal or state income tax returns. According to the most recent estimate, the federal government is estimated to have 49 billion in foregone revenue in 2010 due to millions of households who will itemize charitable deductions in their federal tax returns (Joint Committee on Taxation, 2008). The economic rationales for providing tax subsidies for charitable contributions are well-documented. ${ }^{1}$ Recent literature also documents that the amount of charitable contributions are very responsive to tax subsidies. ${ }^{2}$ However, the indirect effects of charitable subsidies are relatively unknown. ${ }^{3}$ Using a panel data set of individuals, this paper documents the impact of charitable subsidies on religious giving and investigates the spillover effects of such policies on religious participation.

In the United States, religious institutions are the largest recipients of charitable contributions. ${ }^{4}$ In addition, over two-thirds of Americans belong to a church or other religious organization and two-fifths of Americans attend church in a typical week (Iannaccone, 1998). ${ }^{5}$ The existing literature documents that religiosity is a major determinant of well-being among Americans. ${ }^{6}$ Several studies also find a strong association between religious participation and a wide range of economically important social behavior, such as educational attainment, voting behavior, criminal activity, drug and alcohol consumption, physical and mental health, and marriage, fertility and divorce. ${ }^{7}$ Therefore, understanding the direct and indirect effects of charitable subsidies on religious giving and participation is important and findings from empirical analysis may help policymakers to make

\footnotetext{
${ }^{1}$ Andreoni (2006) provides an extensive discussion of the relationship between charitable subsidies and giving.

${ }^{2}$ Recent studies that investigate the impact of tax subsidies on charitable giving include Clotfelter (1990), Randolph (1995), and Auten, Sieg, and Clotfelter (2002). Most estimates in the literature suggest that a $1 \%$ increase in the tax price of giving is associated with more than $1 \%$ decrease in the amount of charitable gifts.

${ }^{3}$ An exception is a handful of studies which investigate the spillover effects of charitable subsidies on volunteering. See, for example, Menchik and Weisbrod (1987), Brown and Lankford (1992), Andreoni, Gale, and Scholz (1996), and Feldman (2010).

${ }^{4}$ According to the most recent estimate of National Center of Charitable Statistics at Urban Institute, religious organizations received the largest share, with $34.7 \%$ of total estimated contributions

${ }^{5}$ Chaves and Stephens (2001) argue that church attendance rates are typically inflated in surveys. However, Gruber (2004) suggests that even at a participation rate half as high, the United States would remain one of the most religious nations in the world.

${ }^{6}$ See, for example, Iannaccone (1998) and Gruber (2004).

${ }^{7}$ Iannaccone (1998) provides an extensive literature review of the impact of religious participation on economic and social outcomes. A recent paper by Gerber, Gruber, and Hungerman (2008) investigates the effect of religiosity on voter turnout and also provides a review of literature on the effects of religiosity on various economic and social outcomes.
} 
informed choices about the spillover effects of charitable subsidies.

The relationship between religious giving and participation is ambiguous. Religious participation can be either a complement to, or a substitute for the level of religious donations. On the one hand, as Gruber (2004) points out, if giving occurs in a religious setting, if individuals wish to monitor the impact of increased levels of their donations, or if the "warm glow" of giving is only operative when participating, then religious giving and attendance could be complementary. In this case, higher subsidies to charitable giving would lead to an increase in religious participation. On the other hand, a classic model of religiosity (Azzi and Ehrenberg, 1975) predicts that giving and religiosity are substitutes. Furthermore, a handful of empirical studies that have previously investigated the relationship between religious giving and attendance provide mixed results. However, the results from the existing studies may be prone to omitted variable bias due to the lack of appropriate panel data that contain information on both religious giving and attendance.

In order to address this shortcoming, in this paper, I use a newly available panel data set of individuals which contains detailed information on religious giving and participation: the philanthropy module of the Panel Study of Income Dynamics (PSID). I argue that this data set has several advantages compared with other data sets of its kind and enables one to control for unobserved individual time-invariant characteristics that may jointly affect religious giving and participation. Following Gruber (2004) and Kim (2007), I exploit the variation in the subsidization of charitable giving in the United States over time, across income levels, and across states and use the aftertax price of giving as an instrument for religious giving in order identify the relationship between religious giving and attendance. I expect that the after-tax price should be negatively correlated with the propensity to give to religious organizations and the amount of religious contributions but uncorrelated with the unobserved variables that may affect religious participation after several time-dependent observable factors and individual fixed effects are controlled for.

The results imply that religious giving and attendance are complements. Increasing the tax price of giving decreases religious contributions but at the same time, negatively affects the religious participation rate. Therefore, policies that encourage religious giving have positive spillover effects on religious attendance. In models that control for the unobserved individual fixed effects, a $1 \%$ increase in the after-tax price of giving is associated with a 0.1 percentage point decrease in the probability of giving to a religious organization and $0.6 \%$ decrease in the amount religious contributions. On the other hand, the implied cross-price elasticity of religious participation with respect to the after-tax price of giving is -0.27 . These results are also robust to the potential 
endogeneity of income and the tax price, and the possible existence of omitted factors that vary jointly by income level and year, jointly by state and year, and jointly by state and income level. Using the after-tax price of charitable giving as an instrument for religious giving, I also document the relationship between religious giving and religious participation. I find that a $1 \%$ increase in the amount of religious contributions is associated with a $0.4 \%$ increase in religious attendance.

The rest of this paper is organized as follows. The next section presents a review of the existing literature on religious giving and attendance. Section three presents the data and discusses the empirical methodology. Section four discusses the results and presents several robustness checks. Section five provides a discussion of policy implications and concludes.

\section{Literature review}

\subsection{Charitable subsidies and religious giving}

There is a sizeable literature devoted to assessing the elasticity of charitable giving with respect to its after-tax price. Andreoni (2006) provides a detailed survey of theoretical and empirical studies in this literature. However, there has been relatively little attention in the literature to the estimation of this elasticity separately for religious giving. Several papers model religious giving explicitly. For instance, McClelland and Kokoski (1994) provide a model of religious giving and using survey data from the early 1980s, they find that religious giving is much less price elastic than non-religious giving. Similarly, using a cross-section of households from PSID, Brooks (2007) finds that compared with other types of charitable contributions, religious giving is less responsive to changes in charitable subsidies. In contrast, using the data of the Survey of Social Development Trends from Taiwan, Chang (2005) finds stronger price effects for religious giving. Bradley, Holden, and McClelland (2005) model total and nonreligious giving, so that religious giving is a residual. They find that religious giving is less price elastic compared with non-religious giving.

The main empirical problem that is widely-discussed in the literature is the endogeneity of the after-tax price of giving. The most common approach to address this problem is to use the first-dollar tax price, which excludes charitable contributions, as an instrument for the after-tax price. An alternative approach is using state tax rates as an instrument for the after-tax price. However, states that adopt different tax rates may differ systematically in unobserved ways. These unobserved differences may affect both the marginal tax rates and giving propensities. In the empirical models presented below, I rely on the extensive variation over time, within income levels, 
and within states to control for both income and fixed state differences in identifying the effect of charitable subsidies. Furthermore, the panel structure of the data allows me to control for unobserved individual factors that might be correlated with both the after-tax price and religious giving. As a robustness check, I also estimate two stage models using the first-dollar price as an instrument for the after-tax price of giving.

\subsection{Charitable subsidies and religiosity}

Azzi and Ehrenberg (1975) provide the first formal theoretical model for the household production of religiosity. In this model, individuals allocate their time and goods among religious and secular commodities so as to maximize lifetime and "afterlife" utility. As individuals allocate more of their time and money to religious commodities, it lowers consumption today, but increases consumption in the afterlife. Iannaccone (1998) argues that this model predicts that time and money devoted to religion are substitutes since afterlife consumption is jointly produced by time and money and as more money is contributed, the marginal utility of time falls for afterlife consumption relative to current consumption.

There are a handful of papers that have formally investigated the relationship between religious giving and participation. The empirical findings are mixed. Olson and Caddell (1994), Forbes and Zampelli (1997), Iannaccone (1997), Dahl and Ransom (1999), and Lunn, Klay, and Douglass (2001) find a positive relationship between attendance and contributions, suggesting complementarity between religious giving and participation. Gruber (2004) argues that these studies suffer from omitted variable bias and fail to control for unobserved factors that may jointly effect giving and religiosity. Sullivan (1985) and Clain and Zech (1999) address this problem by estimating reduced forms of simultaneous equations models which include predicted contributions in participation models and vice versa. Sullivan (1985) assumes that whether one "considers sacramental participation necessary for salvation" is correlated with religious participation but not contributions and that church size and whether one "considers tithing necessary for salvation" affect contributions but not attendance. Clain and Zech (1999) assume that the square of income, home ownership, the square of age, and wife's education affect religious giving but not attendance, and that own education, number of children, and religious preference affect religious participation but not contributions. Both studies conclude that charitable giving and attendance are complements.

However, Gruber (2004) argues that the instruments used in Sullivan (1985) and Clain and Zech (1999) are questionable and it is hard to conceive of exogenous factors (other than tax laws), which 
are correlated with religious contributions but not attendance or vice versa. Then, he argues that charitable subsidies (one minus the after-tax price of giving) vary in ways that are exogenous to both giving and religiosity, providing an independent instrument for identifying the substitutability or complementarity of these two behaviors. Using pooled cross-sections from Consumer Expenditure Survey (CEX), he estimates reduced form models of religious giving and finds that the after-tax price elasticity of giving is -0.47 . Hence a $1 \%$ increase in charitable subsidies is associated with approximately $0.5 \%$ increase in religious giving. Next, he uses pooled cross-sectional data from General Social Survey (GSS) to show that the same magnitude of increase in the subsidy decreases religious participation by $0.5 \%$. Using the impact of subsidies on religious giving and attendance, he concludes that each $1 \%$ rise in charitable giving leads to around $0.6 \%$ to $1.1 \%$ decline in religious attendance, which suggests that these two behaviors are substitutes.

Kim (2007) provides a major criticism for Gruber's findings. He uses pooled cross sectional data from three waves of Survey of Giving and Volunteering in the United States (SGV) and employs the same empirical strategy that Gruber (2004) has used. In sharp contrast to Gruber (2004), he finds that the cross-price elasticity of religious attendance with respect to the after-tax price of giving is -0.4 , which implies that charitable giving and religious attendance are complements. Kim (2007) argues that due to the lack of data, Gruber (2004) imputes itemization status for each respondent, which creates a large amount of non-classical measurement error. He shows that when he also imputes itemization status as opposed to using survey-reported itemization status, he obtains similar results as Gruber (2004).

The empirical analysis presented in this paper is similar to that of Gruber(2004) and Kim (2007). However, this paper uses a panel data set instead of independent cross-sections. This panel data set not only allows one to further control for possible omitted variables that may affect religious giving, attendance, and charitable subsidies but also contains more reliable information on religious attendance and other variables that are used to calculate the after-tax price of giving for each respondent. Furthermore, in contrast to Gruber (2004) and Kim (2007), I explicitly document the relationship between religious giving and attendance in two stage models and separately investigate the effect of charitable subsidies by gender, race, marital status, and religious affiliation. 


\section{Data and empirical strategy}

I use 2003 and 2005 waves of a newly available, nationally representative panel survey on the motivations for charitable giving in the United States: the Center on Philanthropy Panel Study (COPPS), the Philanthropy Module of the PSID. ${ }^{8}$ Compared with the other surveys of its kind such as the SGV, the GSS, and the CEX, the COPPS has several advantages.

First, it is the only panel survey that contains information on religious contributions and attendance and therefore allows one to control for unobserved individual fixed effects that may be correlated with these variables.

Second, in contrast to the GSS and CEX, it contains information on whether the respondent itemized a charitable deduction or not. This information is particularly important to estimate the effect of charitable subsidies on religious giving and attendance since those who do not itemize deductions cannot be subsidized.

Third, in contrast to the SGV and GSS, the COPPS contains very detailed information on several variables that are used to calculate the marginal tax rates such as income and itemized deductions. For instance, the SGV and GSS report income in categories, hence one has to impute the household income in order to calculate the marginal tax rate. ${ }^{9}$ Similarly, neither the SGV nor the GSS contain information on itemized deductions such as health care expenses, mortgage payments, property taxes, rent paid, and child care expenses and therefore, information on these variables has to be imputed in order to calculate the marginal tax rate for each household. ${ }^{10}$

Fourth, in contrast to the SGV and GSS, the COPPS contains more reliable information on religious attendance. The COPPS clearly identifies the number of days that the respondent attended a religious service per week, month, or year, while the SGV and GSS report this information as an index variable. For example, rather than asking the exact number of days of religious attendance, the GSS asks a nationally representative sample of respondents about the frequency of their religious attendance and allows nine possible responses to this question: never, less than once per year, about once or twice a year, several times a year, about once a month, two to three times a month, nearly every week, every week, and several times a week.

\footnotetext{
${ }^{8}$ The COPPS is also available for 2001 and 2007 . However, these waves do not contain information on religious attendance of the respondent.

${ }^{9} \mathrm{Kim}$ (2007) imputes income by using the midpoint of each income category. Gruber (2004) imputes income by using data from Current Population Survey.

${ }^{10}$ Gruber (2004) and Kim (2007) impute the amount of itemized deductions by income level using information from the Statistics of Income (SOI) for each year.
} 
Finally, Wilhelm $(2006,2007)$ argues that the quality of the COPPS data may be superior to that collected in other household surveys of charitable giving because of the PSID staff's experience in collecting data and the respondents' experience with the survey procedure.

I link the information from the COPPS with the PSID individual data on each respondent and create an unbalanced panel of individuals over two years. I restrict my sample to household heads and wives since the PSID contains demographic information only for these groups. Eliminating the observations with missing key variables yields a representative sample of 31092 observations over two years. ${ }^{11}$ Table 1 presents the description of key variables and sample weighted summary statistics. ${ }^{12}$ On average, $50 \%$ percent of the respondents reported contributing to religious organizations with and average contribution of $\$ 1057 .{ }^{13}$ Alternatively, on average, people give $1.3 \%$ of their income to religious organizations. This estimate is comparable with the religious giving rates from other sources of charitable giving data. ${ }^{14}$ The average tax subsidy to charitable giving in the sample is 12.5\%. ${ }^{15}$ Again, this estimate is comparable with the estimates from other sources of charitable giving data. ${ }^{16}$ In the COPPS, there exists a fairly broad distribution of the frequency of attendance at religious services ranging from no attendance to few people reporting attendance every day. On average, people reported attending at a religious service 2.5 times a month. ${ }^{17}$

\footnotetext{
${ }^{11}$ I eliminated several observations due to missing or unreliable information. This includes 163 respondents who reported attending a religious service more than 30 times a month, 104 respondents with unreliable information on educational attainment, 1280 respondents with unreliable information on race, and 3454 respondents with unreliable information on age.

${ }^{12}$ I use PSID's individual weights to calculate the sample weighted summary statistics. Number of observations with non-zero weights is 21572. Although I report the non-weighted regression estimates for the rest of the paper, weighted and non-weighted estimation results are very similar. The weighted regression estimates are available upon request.

${ }^{13}$ The amount of religious contributions and household income are reported in 2005 dollars throughout the paper.

${ }^{14}$ In the CEX, this rate is $1.1 \%$ (Gruber, 2004). In the 2001 edition of the SGV, this rate is $1.5 \%$.

${ }^{15}$ The average tax subsidy is simply calculated as one minus the after-tax price of giving.

${ }^{16}$ Gruber (2004) reports that the average tax subsidy to charitable giving, factoring in the odds of itemization by income is $9.4 \%$ in the CEX, and $10 \%$ in the GSS. I estimate that the average subsidy in the 2001 edition of the SGV is $11.2 \%$. The slightly higher subsidy rates on average in the PSID may be due to the higher levels of average income in this data set.

${ }^{17}$ Each respondent was asked the following two questions (answer choices are in paranthesis): "During the year [survey year], on average, how often did you go to religious services? (number=actual number of times)" and "During the year [survey year], on average, how often did you go to religious services? (time unit=day, week, two weeks, month, or year)". In order to calculate the average number of religious attendance per month, for each respondent, I multiplied the actual number by 30 if the time unit is=day, by $52 / 12$ if the time unit=week, by $26 / 12$ if the time unit=two weeks, and divide the actual number by 12 if the time unit=year.
} 


\subsection{The after-tax price of giving}

In the Unites States, households are allowed to itemize charitable deductions on their federal and most state personal income tax returns. Therefore, each dollar given away to charity costs less than a dollar if the household itemizes deductions. Following the standard practice in the literature, I compute the after-tax price of giving, which incorporates charitable contributions, as $1-t$ for those who itemize deductions and 1 for those who do not, where $t$ is the sum of the federal and state marginal tax rates that the donor faces.

PSID contains a question which obtains information on whether the respondent itemized deductions or not. In order to calculate the marginal tax rates for each individual at a given year, I use National Bureau of Economic Research (NBER)'s TAXSIM model (version 9.0). ${ }^{18}$ This model inputs information on income, state of residence, marital status, number of children, age, child care expenses, itemized deductions such as charitable donations and health care expenses, mortgage interest payments, and property taxes or rent paid and outputs federal and state marginal tax rates for each individual. The information on all these variables are available at PSID. ${ }^{19}$

As Gruber (2004) points out, the resulting after-tax prices of giving vary across the respondents primarily due to the differences in income, state of residence, and time. For instance, high-income taxpayers have relatively higher marginal tax rates, and hence a more sizeable reduction in their tax burden from deductions to their taxable income. There have been significant changes in the schedule of tax rates from 2003 to 2005 at the federal and state level, which are incorporated into the calculation of marginal tax rates. For instance, in addition to several new deductions and credits introduced during this period, tax rates above 15 percent were dropped by 2 percentage points in 2003, new reporting requirements for non-cash charitable contributions were introduced in 2004, and income based limits for cash charitable donations were lifted in $2005 .{ }^{20}$ Finally, tax subsidies to charity vary across states due to the considerable variation in state income tax systems. A number of states follow the federal tax laws, so that charitable contributions are fully

\footnotetext{
${ }^{18}$ The TAXSIM model is available at http://www.nber.org/ taxsim/taxsim-calc9/index.html.

${ }^{19}$ Following Duncan (1999), Andreoni, Brown, and Rischall (2003), Yörük (2009), and Yörük (2010), I assumed that those who are married report joint filing status. Following Gruber (2004), I use total family income instead of using seperate incomes for heads and wifes. Following Reinstein (2010), I solve for the the mortgage interest payment for the first mortgage and ignore second and third mortgages, and approximate by assuming one payment a year. In addition to charitable giving, I also incorporate other deductions such as health care costs. Reinstein (2010) provides a detailed discussion of the computation of the marginal tax rates with TAXSIM model.

${ }^{20}$ IRS regularly publishes highlights of tax law changes for each tax year. For further details of law changes during the 2003-2005 period, one can refer to www.irs.gov.
} 
deductible for itemizers, while some others ask the taxpayer to explicitly report their federally itemized amounts from their state taxable income. Furthermore, several states do not allow a deduction for charitable contributions. Each of these factors, income, time, and state, may be independently correlated with both charitable behavior and with religious attendance. In addition to several other demographic variables, the empirical models explicitly control for the effects of these variables.

\subsection{Empirical strategy}

The empirical model follows that of Gruber (2004) and Kim (2007) with a key difference of the inclusion of unobserved individual effects as additional controls. Hence, I estimate several fixedeffects models that are of the following general form:

$$
Y_{i s t}=\beta^{\prime} X_{i s t}+\gamma \text { inc }_{i s t}+\text { aprice }_{i s t}+\delta_{s}+\eta_{t}+\mu_{i}+\epsilon_{i s t}
$$

where $Y$ denotes one of the outcomes (whether the respondent donated to a religious organization, the amount of her religious contributions, and her average number of days of religious attendance per month), $X$ is a set of demographic control variables, inc is the natural logarithm of household income, price is the natural logarithm of the after-tax price of giving, $\delta_{s}$ is the full set of state effects, $\eta_{t}$ is the fixed time effect which is equal to unity for $2005, \mu_{i}$ is the individual fixed effects which controls for unobserved individual effects that are time-invariant but may affect the outcome variables, and $\epsilon$ is the residual disturbance term that is assumed to be uncorrelated with $X$ 's, inc, price, $\delta_{s}, \eta_{t}$, and $\mu_{i}{ }^{21}$

The set of demographic controls, $X$, consists of time-dependent individual specific variables such as family size, number of children under 18 years old, binary controls for employment, marital status, and educational attainment. ${ }^{22}$ In addition to unobserved individual effects that are time-invariant, the above model controls for direct effects of income, state of residence, and time. However, as robustness checks, I also estimate models that control for the interactions of income, state, and year, and that address the possible endogeneity of income and the after-tax price and the censored

\footnotetext{
${ }^{21}$ I also estimate models without controlling for the state fixed effects. The estimates from these models are very similar to those presented in this paper. This suggests that although there is a variation in the tax rates at the state level, the main source of identification in empirical models is the changes in federal tax laws over time.

${ }^{22}$ Definition of control variables are presented in Table 1. All nominal variables are expressed in 2005 dollars. As a benchmark, I also estimate OLS models by pooling data from two different time periods. In addition to timedependent characteristics, these models also control for time-invariant individual characteristics such as gender, race, and age.
} 
or binary nature of the dependent variables.

\section{Results}

\subsection{The impact of charitable subsidies on the probability of giving to religious organizations}

Table 2 reports the effect of charitable subsidies on the probability of giving to religious organizations. ${ }^{23}$ The first column presents the estimates from the benchmark ordinary least squares (OLS) model, which does not control for unobserved individual fixed effects that may affect the probability of giving to religious organizations. As expected, the probability of giving goes down as the after-price of giving goes up (the charitable subsidy goes down). For the full sample, this model suggests that a $1 \%$ increase in the after-tax price of giving is associated with a 0.42 percentage point decrease in the probability of giving to a religious organization. I also estimate this effect by gender, race, marital status, and religious affiliation. The impact of charitable subsidies on the probability of giving to a religious organization differs considerably by race, but not by gender. On average, whites are less responsive to charitable subsidies compared with blacks. A $1 \%$ increase in the after-tax price of giving decreases whites' probability of religious giving by 0.37 percentage points, whereas the same magnitude of increase in the tax price is associated with a 0.75 percentage point decrease in blacks' probability of giving to religious organizations. Unmarried respondents appear to be more responsive to charitable subsidies. For this group, the after-tax price elasticity of the probability of religious giving is -0.56. A majority of the sample in the COPPS consists of Protestants and Catholics. ${ }^{24}$ Estimating separate regressions for these groups, I find that Protestants are more responsive to charitable subsidies compared with Catholics. The probability of religious giving for Catholics goes down by 0.31 percentage points as a response to a $1 \%$ increase in the tax price of giving, whereas Protestants decrease their probability of religious giving by 0.45 percentage points as a response to the same magnitude of change in the tax price.

Although the tax price of the last dollar contributed is the most economically meaningful, it also depends on the donation amount. In order to address the possible endogeneity of the after-

\footnotetext{
${ }^{23}$ In these models, the dependent variable is a binary variable which is equal to one if the respondent reported donating to a religious organization during the survey year.

${ }^{24}$ Although the COPPS contain information on other religious preferences, more that $85 \%$ of the sample is either Catholic or Protestant. Here, I report separate regression results only for these two groups. The results for other religious groups are available upon request.
} 
tax price of giving, I instrument this variable with the first-dollar price of giving and reestimate a two stage least squares (2SLS) model. ${ }^{25}$ The results reported in the second column of Table 2 show that controlling for endogeneity of the after-tax price slightly increases the estimated effect of the charitable subsidies for all groups. For the full sample, 2SLS model suggests that a $1 \%$ increase in the after-tax price of giving is associated with a 0.44 percentage point decrease in the probability of giving to a religious organization. Furthermore, this effect remains highly significant. The OLS and 2SLS models do not control for the discrete nature of the outcome variable. In order to address this problem, I estimate several probit type models. The marginal effects from these models reported in the third and fourth columns of Table 2 show that compared with the OLS models, probit type models yield a smaller impact of the after-tax price on the probability of giving to religious organizations. The last two columns of Table 2 report estimates from the fixed effects (FE) models. ${ }^{26}$ Compared with OLS, 2SLS, Probit, and IV-Probit models, FE and IV-FE models yield considerably smaller effect of the after-tax price on the probability of giving to a religious organization. In both models, for the full sample, a 1\% increase in the after-tax price of giving is associated with a 0.1 percentage point decrease in the probability of giving to a religious organization. Furthermore, for blacks and Catholics, this effect is not statistically significant at conventional significance levels.

\subsection{The impact of charitable subsidies on the amount of religious contributions}

Table 3 presents the estimated effect of charitable subsidies on the amount of religious contributions under different specifications. ${ }^{27}$ For the full sample, OLS and Tobit models suggest that the amount of religious contributions tend to decrease by $2.1 \%$ to $3.5 \%$ as a response to a $1 \%$ increase in the

\footnotetext{
${ }^{25}$ The first-dollar tax price, which is the marginal tax rate that applies to the first dollar donated to the charity, is a widely used instrument in the literature (Andreoni, 2006). I use TAXSIM model to calculate this variable under the assumption that the respondents do not claim a charitable deduction. For 2SLS and IV-Probit models, in the first stage, I estimate an OLS regression of the after-tax price on the first-dollar price and other control variables. For the IV-FE model, in the first stage, I estimate a FE regression of the after-tax price on the first-dollar price and time-dependent control variables. In all regressions, the coefficient of the first-dollar price is significant at $1 \%$ significance level. These results are presented in Appendix Table A2.

${ }^{26} \mathrm{I}$ also estimate corresponding random effects models which assume that unobserved individual fixed effects are uncorrelated with the independent variables. However, Hausman tests suggest that the FE models are appropriate for the full sample and all subsamples. Hence, I only report estimates from the FE models. The detailed estimates from the FE models are reported in Appendix Table A1. Estimates from the random effects models are available upon request.

${ }^{27}$ In these models, the dependent variable is $\log$ (amount of religious contributions +1 ). I add one to the amount of religious contributions so that the log-transformed variable is still censored at zero. This is a standard practice in the literature.
} 
after-tax price. Models that control for the possible endogeneity of charitable subsidies using the first-dollar price of giving as an instrument, namely 2SLS and IV-Tobit models, yield comparable estimates. Estimates from the FE and IV-FE models reported in the last two columns of Table 3 show that the effect of charitable subsidies on religious giving is much smaller once the unobserved individual effects are controlled for. These models suggest that a $1 \%$ increase in the after-tax price of giving is associated with around $0.6 \%$ decrease in the amount religious contributions. ${ }^{28}$ On average, this corresponds to a $\$ 6$ increase in religious donations as a response to each percentage point increase in the charitable subsidy. In general, the estimated effect of the after-tax price on the amount of religious contributions is robust to the selection of the sample based on gender, race, marital status, and religious affiliation, except for Catholics. Catholics tend to decrease their religious giving by $0.2 \%$ to $0.3 \%$ as a response to a $1 \%$ increase in the after-tax price of giving. However, this effect is not statistically significant.

\subsection{The impact of charitable subsidies on religious attendance}

The above analysis confirms the findings of earlier literature and documents that religious giving is quite sensitive to charitable subsidies. This section turns to an analysis of the impact of charitable subsidies on religious attendance. In contrast to Gruber (2004), Table 4 shows that charitable subsidies have a positive impact on religious attendance, which suggests that religious giving and attendance are economic complements. ${ }^{29}$ Results from the OLS and Tobit models reported in the first two columns suggest that a $1 \%$ increase in charitable subsidies is associated with around $0.5 \%$ to $0.6 \%$ increase in religious attendance. The effect of the charitable subsidies on religious attendance decreases considerably when the unobserved individual fixed effects are controlled for. Estimates from the FE models reported in the third column of Table 4 suggests that religious attendance decreases by $0.27 \%$ as a response to a $1 \%$ increase in the after-tax price of giving. This effect is relatively small but highly significant. On average, people reported attending a religious

\footnotetext{
${ }^{28}$ Although OLS and Tobit models yield similar results, Honore (1992) proposes a method to estimate a censored outcome model with fixed effects in a panel data setting. The practical difficulty in implementing this estimator is to calculate the marginal effects after the regression. However, in this model, the coefficient on the after-tax price remains to be negative and highly significant which suggests that charitable subsidies increase religious contributions. These results are available upon request.

${ }^{29}$ In the first three columns, the dependent variable is $\log$ (number of days that the respondent reported attending a religious service per month+0.1). In order to check the sensitivity of estimates to this transformation, the last three columns report estimates from the models in which the outcome variable is in the level form. In all models, following Gruber (2004), the main identifying assumption is that the after-tax price of giving affects religious attendance only through religious giving.
} 
service 2.5 times a month. Hence, at the mean of the sample, a $10 \%$ increase in charitable subsidies increases religious attendance by 0.07 days per month. Compared with the full sample, blacks and unmarried people are more responsive to charitable subsidies. A 1\% increase in the after-tax price decreases religious attendance by $0.8 \%$ for blacks and by $0.6 \%$ for unmarried respondents. On the other hand, the FE models estimated for different groups show that although the effect of charitable subsidies on religious attendance remains positive, it is insignificant for whites and Catholics.

The last three columns in Table 4 present comparable models in which the outcome variable is in the level form, i.e., the average number of days that the respondent reported attending a religious service per month. Compared with the models estimated using the log transformed outcome, these models generate a slightly smaller impact of charitable subsidies on religious attendance. For the full sample, they suggest that when the after-tax price goes up by $10 \%$, people tend to decrease their religious attendance by 0.04 days per month. The FE models suggest that for females, blacks, unmarrieds, and Protestants, a same magnitude of increase in the after-tax price is associated with a $0.06,0.18,0.14$, and 0.08 days per month decrease in religious participation respectively. The impact of the after-tax price remains insignificant for males, whites, and Catholics. Furthermore, these estimates are quite similar to, but slightly lower than the estimates from Kim (2007), who finds that the tax price elasticity of religious attendance is -0.4 .

\subsection{Robustness checks}

A potential concern with the above approach is the endogeneity of incomes to religiosity. If more time spent at religious services reduces the time available to generate income, this could decrease the subsidy to charitable giving and impose a bias to above estimates. Alternatively, if those who attend religious services frequently are also those who earn more, this could raise the tax subsidy to charitable giving and impose a positive bias to the relationship estimated in Table 4. In order to address the potential endogeneity of income, I follow two distinct approaches. First, following Gruber (2004), I reestimate religious participation models using predicted income to compute the after-tax price of giving instead of the actual income. For this, I first predict household income based on the exogenous characteristics included in the empirical models such as age, sex, race, marital status, family size, number of children, educational attainment, and employment status. I then use this predicted income to calculate marginal tax rates in the same fashion as with actual income. ${ }^{30}$ Table 5 reports the results of this approach. The impact of the charitable subsidies

\footnotetext{
${ }^{30}$ I use TAXSIM model to calculate the marginal tax rates with this alternative measure of income.
} 
on religious attendance remains positive and highly significant. The results from the alternative models suggest that when the price of charitable giving goes up by $1 \%$, religious attendance tend to go down by $0.2 \%$ to $1 \%$. Alternative specifications of the religious participation models reported in the last three columns of Table 5 yield comparable estimates. These models suggest that a 10\% increase in the after-tax price increases religious attendance by around 0.03 to 0.12 days per month.

As an alternative approach, I also follow Gruber and Saez (2002) and exploit the exogenous changes in marginal tax rates for a given income. That is, I estimate the change in tax price for each individual by holding income constant in both periods and estimate the tax price in each period at the same income level. Since income is held fixed, changes in the tax price for each individual is due to changes in tax policy over time and the tax price change is truly exogenous with respect to each individual. The results from this alternative approach implies that religious attendance decreases by $0.2 \%$ to $0.6 \%$ in response to a $1 \%$ increase in the after-tax price. Similarly, a $10 \%$ increase in the after-tax price decreases religious attendance by around 0.03 to 0.05 days per month. Hence, the estimates from the main models are robust to the potential endogeneity of income.

The remaining specifications reported in Table 5 address the potential omitted factors that may be correlated with both charitable subsidies and religious participation. These models include interactions between income and year, state and year, and state and income as additional controls. The interaction between household income and year captures any potential national shocks that may have occurred over time and that may have a heterogenous effect on different income groups. Inclusion of this interaction term does not change the impact of charitable subsidies on religious participation. The FE model suggests that the elasticity of religious attendance with respect to after-tax price remains to be -0.27 .

The interactions between state and year dummies absorb any changes in states over time that has the same impact on all income levels. Inclusion of these interaction terms to religious participation models does not change the key coefficient on the after-tax price of giving. Compared with the full-sample results reported in Table 4, the impact of the after-tax price on religious participation remains virtually the same.

The interaction dummies between income and each state dummy captures any differences in religious participation by income level across states. Again, inclusion of these interaction dummies changes the coefficient on the after-tax price only slightly and in this specification, the elasticity of religious attendance with respect to the after-tax price is -0.25 . Therefore, in addition to the unobserved individual effects that are time-invariant, the estimated negative impact of charitable 
subsidies on religious participation cannot be explained by the existence of omitted variables that vary jointly by income level and year, jointly by state and year, and jointly by state and income level..$^{31}$

\subsection{The impact of religious giving on religious attendance}

So far, I presented the results from several reduced form models that identify the relationship between charitable subsidies and religious giving and attendance. In this section, I investigate the relationship between religious giving and religious participation using the after-tax price of giving as an instrument for religious giving. I report results from 2SLS, IV-Tobit, and IV-FE models. In these models, the main identifying assumption is that the after-tax price of giving affects religious participation only through religious giving. ${ }^{32}$ Therefore, after-tax price of giving should satisfy two conditions. It must be a significant determinant of charitable giving and it must be uncorrelated with the unobserved covariates that may affect religious attendance. Although one cannot test whether the second condition is satisfied, Tables 2 and 3 clearly show that in the first stage regressions, after-tax price is a significant determinant of the probability of giving and the amount of contributions to religious organizations.

I start with investigating the impact of the probability of giving to a religious organization on religious participation. The results from the 2SLS and IV-Tobit models reported in Table 6 suggest that compared with those who do not give to religious organizations, those who donate to religious organizations allocate around $123 \%$ to $141 \%$ more time for religious participation. The IV-FE model suggests that this effect is much higher once the unobserved individual effects are controlled for. The IV-FE estimate implies that once those who do not contribute to religious causes start to contribute to religious organizations, their religious participation, on average, is expected to increase by $274 \%$. The impact of the probability of giving to a religious organization on religious attendance is positive and highly significant for all sub-groups in 2SLS and IV-Tobit models. However, IV-FE models estimated separately for whites, blacks, and Catholics reveal that this effect is insignificant for these groups once the individual fixed effects are controlled for.

The last three columns of Table 3 document the effect of the amount of religious contributions

\footnotetext{
${ }^{31} \mathrm{I}$ also include all three interaction terms jointly to religious participation models. These models yield similar estimates.

${ }^{32}$ In these models, the dependent variable is $\log$ (number of days that the respondent reported attending a religious service per month+0.1). Using the level dependent variable instead of the log trasformated outcome yields comparable estimates.
} 
on religious participation. The 2SLS and IV-Tobit models suggest that a $1 \%$ increase in the amount of religious contributions is associated with around $0.15 \%$ to $0.17 \%$ increase in the number of days that the respondent reported participating a religious service. The IV-FE model generates a larger impact of religious giving on religious participation. In this model, a $1 \%$ increase in the amount of religious contributions is associated with a $0.42 \%$ increase in religious attendance. Compared with other groups, the impact of religious giving on religious participation is relatively larger for blacks. Furthermore, IV-FE models estimated separately for whites and Catholics show that this effect is insignificant for these groups.

\section{Discussion of results and conclusion}

Policymakers promote tax reliefs for charitable donors who itemize their donations in their federal and state tax returns. However, the existing literature mostly focuses on the immediate effect of such policies on charitable contributions and often ignore their spillover effects. Most charitable giving by individuals in the U.S. goes to religious causes. Although one would expect that charitable subsidies encourage religious giving, there may also be offsetting costs to subsidizing charity if giving to religious causes and religious participation are substitutes. Although few studies have investigated the relationship between religious giving and attendance, they offer mixed results and use cross-sectional data due to the lack of panel surveys that contain information on both religious giving and participation.

In this paper, I investigate the spillover effects of charitable subsidies on religious attendance using the COPPS, a newly available panel data set of religious giving and participation. Compared with other surveys of its kind, the COPPS contains more reliable information on religious attendance and allows one to control for unobserved time-invariant individual effects that may jointly affect religious giving and participation. Following Gruber (2004) and Kim (2007), I use the after-tax price of giving as an independent instrument for identifying the substitutability or complementarity of religious giving and attendance.

In contrast to Gruber (2004), using the FE models that control for unobserved individual factors that may be correlated with religious giving and participation, I document that religious giving and attendance are economic complements. Hence, policies that encourage religious giving have positive spillover effects on religious attendance. A $1 \%$ increase in the after-tax price of giving is associated with a 0.4 percentage point decrease in the probability of giving to a religious organization and 
$0.6 \%$ decrease in the amount religious contributions. The same magnitude of increase in the aftertax price of giving also decreases religious participation by $0.27 \%$. Furthermore, these results are robust to the potential endogeneity of income and tax price, and the possible existence of omitted factors that vary jointly by income group and year, jointly by state and year, and jointly by state and income group.

Using the after-tax price as an instrument for the probability of contributing to religious organizations and the amount of religious donations, I also document the causal link between religious giving and religious participation. In the FE models, I find that those who give to religious organizations allocate $274 \%$ more time for participating religious services than those who do not donate to religious organizations. Similarly, a $1 \%$ increase in the amount of religious contributions is associated with a $0.42 \%$ increase in religious attendance.

My estimate of the cross-price elasticity of religious giving with respect to the after-tax price is slightly lower than, but similar to the estimate of Kim (2007), who shows that Gruber's estimates may be prone to a measurement error. In addition to the potential measurement error in Gruber's estimates, the differences between my results and those by Gruber can also be attributed to the different time periods covered. ${ }^{33}$ Since the GSS does not obtain data on religious giving for the 20032005 period, it is not possible to test sensitivity of my results using data from the GSS. However, several previous studies that have used data from alternative time periods such as 1963 (Sullivan, 1985), 1994 (Clain and Zech, 1999), 1991-1995 (Kim, 2007), 1996 (Dahl and Ransom, 1999 and Lunn, Klay, and Douglass, 2001) also find that religious giving and attendance are complements. This suggests that the selection of the time period does not have a significant impact on my findings.

The results of this paper highlight the positive externalities created by charitable subsidies and provide insights for alternative theoretical or empirical models which may investigate the indirect effects of charitable subsidies on other types of prosocial behavior. Given the existing literature that relates well-being, happiness, and several other social and economic outcomes to religiosity, a positive effect of charitable subsidies on religious participation would suggest that such an increase in religiosity could have a considerable positive impact on these outcomes. For instance, prior work has found that those who report attending church weekly are between 10 and 15 percentage points more likely to vote (Rosenstone and Hansen 1993; Verba, Schlozman, and Brady 1995). Therefore, given my estimate that a $10 \%$ decrease in the after-tax price increases religious attendance by 0.07 days per month, the same magnitude of decrease in the after-tax price would increase voter-turnout

\footnotetext{
${ }^{33}$ Gruber (2004) uses data from the GSS for the 1977-2000 period.
} 
by around 0.2 percentage points. Cohen-Zada and Sander (2010) document that a one unit increase in the church attendance index (a $23 \%$ increase from its mean) increases the probability of being at least pretty happy relative to not happy by more than 7 percentage points. Given my baseline estimate that religious attendance decreases by $0.3 \%$ as a response to a $1 \%$ increase in the after-tax price of giving, a 10\% increase in the after-tax price would decrease the probability of being at least pretty happy relative to not happy by around 0.9 percentage points. Moreover, adults who never attend religious services are 12.5 percentage points more likely to drink, 14.2 percentage points more likely to smoke, and 6.1 percentage points more likely to have used an illicit drug than those who attend religious services at least weekly (National Center on Addiction and Substance Abuse, 2001). Hence, according to my estimates, a $10 \%$ decrease in the after-tax price would decrease probability of drinking by 0.2 percentage points, probability of smoking by 0.25 percentage points, and probability of drug use by 0.1 percentage points. Although these rough estimates provide some evidence on the positive impact of charitable subsidies on several social and economic outcomes, further research is needed to establish such relationships.

\section{References}

[1] Andreoni, J.E., W.G. Gale, J.K. Scholz, 1996, Charitable contributions of time and money, Unpublished Manuscript, University of Wisconsin.

[2] Andreoni, J., E. Brown, and I. Rischall, 2003, Charitable giving by married couples: Who decides and why does it matter?, Journal of Human Resources, 38, 111-133.

[3] Andreoni, J., 2006, Philanthropy, Handbook of Giving, Reciprocity and Altruism, S-C. Kolm and J. Mercier Ythier, eds., Amsterdam, North Holland, 1201-1269.

[4] Auten, G., H. Sieg, and C.T. Clotfelter, 2002, Charitable giving, income, and taxes: An analysis of panel data, American Economic Review, 92, 371-382.

[5] Azzi, C. and R.G. Ehrenberg, 1975, Household allocation of time and church attendance, Journal of Political Economy, 96, 1066-1088.

[6] Bradley, R., S. Holden, R. McClelland, 2005, A robust estimation of the effects of taxation on charitable contributions, Contemporary Economic Policy, 23, 545-554. 
[7] Brooks, A., 2007, Income tax policy and charitable giving, Journal of Policy Analysis and Management, 26, 599-612.

[8] Brown, E. and H. Lankford, 1992, Gifts of money and time: Estimating the effects of tax prices and available time, Journal of Public Economics, 47, 321-341.

[9] Chang, W., 2005, Religious giving, non-religious giving, and after-life consumption, Topics in Economic Analysis 85 Policy, 5, Article 13.

[10] Chaves, M. and L. Stephens, 2001, Church attendance in the United States. In: Dillon, M. (Ed.), Handbook for the Sociology of Religion. Cambridge Univ. Press, Cambridge, UK, pp. $85-95$.

[11] Clain, S. and C. Zech, 1999, A household production analysis of religious and charitable activity, American Journal of Economics and Sociology, 58, 924-946.

[12] Clotfelter, C.T., 1990, The impact of tax reform on charitable giving: A 1989 perspective, in J. Slemrod Eds., Do taxes matter? The impact of the tax reform act of 1986, Cambridge, MIT Press.

[13] Cohen-Zada, D. and W. Sander, 2010, Religious participation versus shopping: What makes people happier?, Working Paper No. 5198, IZA Bonn.

[14] Dahl, G. and M. Ransom, 1999, Does where you stand depend on where you sit? Tithing donations and self-serving beliefs, American Economic Review, 89, 703-727.

[15] Duncan, B., 1999, Modelling charitable contributions of time and money, Journal of Public Economics, 72, 213-242.

[16] Feldman, N.E., 2010, Time is money: Choosing between charitable activities, American Economic Journal: Economic Policy, 1, 103-130.

[17] Forbes, K. and E. Zampelli, 1997, Religious giving by individuals: A cross-denominational study, American Journal of Economics and Sociology, 56, 17-30.

[18] Gerber, A., J. Gruber, and D.M. Hungerman, 2008, Does church attendance cause people to vote? Using blue laws' repeal to estimate the effect of religiosity on voter turnout, NBER Working Paper No.14303. 
[19] Gruber, J. and E. Saez, 2002, The elasticity of taxable income: Evidence and implications, Journal of Public Economics, 84, 1-32.

[20] Gruber, J., 2004, Pay or Pray? The impact of charitable subsidies on religious attendance, Journal of Public Economics, 88, 2635-2655.

[21] Honore, B.E., 1992, Trimmed lad and least squares estimation of truncated and censored regression models with fixed effects, Econometrica, 60, 533-565.

[22] Iannaccone, L., 1997, Skewness explained: A rational choice model of religious giving, Journal for the Scientific Study of Religion, 36, 141-157.

[23] Iannaccone, L., 1998, Introduction to economics of religion, Journal of Economic Literature, $36,1465-1496$.

[24] Joint Committee on Taxation, 2008, Estimates of Federal Tax Expenditures for Fiscal Years 2008-2012, U.S. Government Printing Office, Washington, DC.

[25] Kim, M., 2007, Three essays in public economics, Ph.D. Dissertation in Economics, University of Wisconsin, Madison.

[26] Lunn, J., R. Klay, and A. Douglass, 2001, Relationships among giving, church attendance, and religious belief: The case of Presbyterian Church (USA), Journal for the Scientific Study of Religion, 40, 765-775.

[27] Menchik, P. and B.A. Weisbrod, Volunteer Labor Supply, 1987, Journal of Public Economics, $32,159-183$.

[28] McClelland R. and M.F. Kokoski, 1994, Econometric issues in the analysis of charitable giving, Public Finance Review, 22, 498-517.

[29] National Center on Addiction and Substance Abuse, 2001, So help me god: Substance abuse, religion, and spirituality, Columbia University, New York, NY.

[30] Olson, D. and D. Caddell, 1994, Generous congregations, generous givers: Congregational contexts that stimulate individual giving, Review of Religious Research, 36, 168-180.

[31] Reinstein, D., 2010, Does one charitable contribution come at the expense of another?, forthcoming in B.E. Journal of Economic Analysis and Policy (Contributions/Advances). 
[32] Randolph, W.C., 1995, Dynamic income, progressive taxes, and the timing of charitable contributions, Journal of Political Economy, 103, 709-738.

[33] Rosenstone, S.J. and J.M. Hansen, 1993, Mobilization, participation, and democracy in America, MacMillan, New York, NY.

[34] Sullivan, D., 1985, Simultaneous determination of church contributions and church attendance, Economic Inquiry, 23, 309-320.

[35] Verba, S., K.L. Schlozman, and H. Brady, 1995, Voice and equality: Civic Voluntarism in American Politics, Harvard University Press, Cambridge, MA

[36] Wilhelm, M., 2006, New data on charitable giving in the PSID, Economics Letters, 92, 26-31.

[37] Wilhelm, M., 2007, The quality and comparability of survey data on charitable giving, Nonprofit and voluntary sector quarterly, 36, 65-84.

[38] Yörük, B.K., 2009, How responsive are charitable donors to requests to give?, Journal of Public Economics, 93, 1111-1117.

[39] Yörük, B.K., 2010, Charitable giving by married couples revisited, Journal of Human Resources, 45, 497-516. 
Table 1. Description of key variables and summary statistics

\begin{tabular}{|c|c|c|c|}
\hline Variable name & Definition & Mean & S.D. \\
\hline Give & $=1$ if the respondent contributed money to religious organizations during the survey year. & 0.501 & 0.500 \\
\hline Amount of religious contributions & $\begin{array}{l}\text { Total amount of religious contributions in } 2005 \text { dollars, including contributions of family } \\
\text { members. }\end{array}$ & 1057.54 & 2909.25 \\
\hline Religious attendance & $\begin{array}{l}\text { Average number of days per month that the respondent reported attending a religious } \\
\text { service. }\end{array}$ & 2.505 & 3.399 \\
\hline Tax price of giving & $\begin{array}{l}=1 \text { minus marginal tax rate for itemizers and } 1 \text { for non-itemizers. Tax rates are calculated } \\
\text { using NBER's TAXSIM calculator. }\end{array}$ & 0.875 & 0.142 \\
\hline Income & Total household income in 2005 dollars. & 78582.82 & 122225.90 \\
\hline Family size & Number of people in the household including the respondent. & 3.032 & 1.522 \\
\hline Children & Number of children in the household, 18 years old and younger. & 1.013 & 1.234 \\
\hline Age & Age of the respondent. & 47.25 & 15.21 \\
\hline Female & $=1$ if the respondent is female. & 0.511 & 0.500 \\
\hline Employed & $=1$ if the respondent is employed. & 0.746 & 0.436 \\
\hline Married & $=1$ if the respondent is married. & 0.673 & 0.469 \\
\hline High school & $=1$ if the highest level of education obtained by the respondent is a high school degree. & 0.438 & 0.496 \\
\hline College & $=1$ if the respondent obtained a four-year college or higher degree. & 0.414 & 0.492 \\
\hline Graduate & $=1$ if the respondent obtained a graduate degree. & 0.112 & 0.315 \\
\hline Black & $=1$ if the respondent is black. & 0.136 & 0.342 \\
\hline White & $=1$ if the respondent is white. & 0.808 & 0.394 \\
\hline
\end{tabular}

Notes: Sample weighted means are reported. Total number of observations is 31092 . Number of observations with non-zero weights is 21537. 
Table 2. The effect of charitable subsidies on the probability of giving to religious organizations

\begin{tabular}{|c|c|c|c|c|c|c|c|}
\hline & No. of Obs. & OLS & 2SLS & Probit & IV-Probit & $\mathrm{FE}$ & IV-FE \\
\hline Full sample & 31092 & $\begin{array}{c}-0.417 \\
(0.023)^{* * *}\end{array}$ & $\begin{array}{c}-0.441 \\
(0.023)^{* * *}\end{array}$ & $\begin{array}{c}-0.354 \\
(0.021)^{* * *}\end{array}$ & $\begin{array}{c}-0.380 \\
(0.021)^{* * *}\end{array}$ & $\begin{array}{c}-0.098 \\
(0.029)^{* * *}\end{array}$ & $\begin{array}{c}-0.100 \\
(0.029)^{* * *}\end{array}$ \\
\hline Male & 14920 & $\begin{array}{c}-0.427 \\
(0.032)^{* * *}\end{array}$ & $\begin{array}{c}-0.450 \\
(0.033)^{* * *}\end{array}$ & $\begin{array}{c}-0.364 \\
(0.031)^{* * *}\end{array}$ & $\begin{array}{c}-0.392 \\
(0.031)^{* * *}\end{array}$ & $\begin{array}{c}-0.092 \\
(0.040)^{* *}\end{array}$ & $\begin{array}{c}-0.094 \\
(0.041)^{* *}\end{array}$ \\
\hline Female & 16172 & $\begin{array}{c}-0.410 \\
(0.032)^{* * *}\end{array}$ & $\begin{array}{c}-0.432 \\
(0.032)^{* * *}\end{array}$ & $\begin{array}{c}-0.345 \\
(0.030)^{* * *}\end{array}$ & $\begin{array}{c}-0.370 \\
(0.030)^{* * *}\end{array}$ & $\begin{array}{c}-0.104 \\
(0.041)^{* * *}\end{array}$ & $\begin{array}{c}-0.107 \\
(0.041)^{* * *}\end{array}$ \\
\hline White & 18714 & $\begin{array}{c}-0.366 \\
(0.028)^{* * *}\end{array}$ & $\begin{array}{c}-0.396 \\
(0.028)^{* * *}\end{array}$ & $\begin{array}{c}-0.330 \\
(0.027)^{* * *}\end{array}$ & $\begin{array}{c}-0.365 \\
(0.027)^{* * *}\end{array}$ & $\begin{array}{c}-0.142 \\
(0.032)^{* * *}\end{array}$ & $\begin{array}{c}-0.145 \\
(0.032)^{* * *}\end{array}$ \\
\hline Black & 10829 & $\begin{array}{c}-0.745 \\
(0.046)^{* * *}\end{array}$ & $\begin{array}{c}-0.753 \\
(0.046)^{* * *}\end{array}$ & $\begin{array}{c}-0.588 \\
(0.041)^{* * *}\end{array}$ & $\begin{array}{c}-0.596 \\
(0.042)^{* * *}\end{array}$ & $\begin{array}{l}-0.074 \\
(0.060)\end{array}$ & $\begin{array}{l}-0.077 \\
(0.060)\end{array}$ \\
\hline Unmarried & 11476 & $\begin{array}{c}-0.561 \\
(0.043)^{* * *}\end{array}$ & $\begin{array}{c}-0.574 \\
(0.043)^{* * *}\end{array}$ & $\begin{array}{c}-0.425 \\
(0.036)^{* * *}\end{array}$ & $\begin{array}{c}-0.437 \\
(0.036)^{* * *}\end{array}$ & $\begin{array}{c}-0.192 \\
(0.065)^{* * *}\end{array}$ & $\begin{array}{c}-0.192 \\
(0.065)^{* * *}\end{array}$ \\
\hline Protestant & 20949 & $\begin{array}{c}-0.451 \\
(0.028)^{* * *}\end{array}$ & $\begin{array}{c}-0.477 \\
(0.028)^{* * *}\end{array}$ & $\begin{array}{c}-0.386 \\
(0.027)^{* * *}\end{array}$ & $\begin{array}{c}-0.415 \\
(0.027)^{* * *}\end{array}$ & $\begin{array}{c}-0.110 \\
(0.036)^{* * *}\end{array}$ & $\begin{array}{c}-0.113 \\
(0.036)^{* * *}\end{array}$ \\
\hline Catholic & 5581 & $\begin{array}{c}-0.311 \\
(0.049)^{* * *}\end{array}$ & $\begin{array}{c}-0.327 \\
(0.049)^{* * *}\end{array}$ & $\begin{array}{c}-0.285 \\
(0.047)^{* * *}\end{array}$ & $\begin{array}{c}-0.306 \\
(0.047)^{* * *}\end{array}$ & $\begin{array}{l}-0.047 \\
(0.061)\end{array}$ & $\begin{array}{l}-0.054 \\
(0.061)\end{array}$ \\
\hline
\end{tabular}

Notes: The effect of log(after-tax price of giving) on the decision to give to a religious organization is reported. All regressions include a set of control variables, and state and year effects as discussed in the text and as presented in Table 1. FE and IV-FE models also control for individual fixed effects but exclude timeinvariant covariates such as gender, race, and age. Average marginal effects are reported for Probit and IV-Probit models. Robust standard errors clustered at the individual level are reported in parentheses. The signs *, **, and *** indicate that the estimate is statistically significant at 10,5 , and 1 percent significance levels respectively. 
Table 3. The effect of charitable subsidies on the amount of religious contributions

\begin{tabular}{|c|c|c|c|c|c|c|c|}
\hline & No. of Obs. & OLS & 2SLS & Tobit & IV-Tobit & $\mathrm{FE}$ & IV-FE \\
\hline Full sample & 31092 & $\begin{array}{c}-3.461 \\
(0.160)^{* * *}\end{array}$ & $\begin{array}{c}-3.735 \\
(0.162)^{* * *}\end{array}$ & $\begin{array}{c}-2.134 \\
(0.122)^{* * *}\end{array}$ & $\begin{array}{c}-2.277 \\
(0.122)^{* * *}\end{array}$ & $\begin{array}{c}-0.630 \\
(0.186)^{* * *}\end{array}$ & $\begin{array}{c}-0.670 \\
(0.188)^{* * *}\end{array}$ \\
\hline Male & 14920 & $\begin{array}{c}-3.504 \\
(0.229)^{* * *}\end{array}$ & $\begin{array}{c}-3.785 \\
(0.232)^{* * *}\end{array}$ & $\begin{array}{c}-2.212 \\
(0.176)^{* * *}\end{array}$ & $\begin{array}{c}-2.359 \\
(0.177)^{* * *}\end{array}$ & $\begin{array}{c}-0.604 \\
(0.263)^{* *}\end{array}$ & $\begin{array}{c}-0.645 \\
(0.265)^{* *}\end{array}$ \\
\hline Female & 16172 & $\begin{array}{c}-3.422 \\
(0.224)^{* * *}\end{array}$ & $\begin{array}{c}-3.691 \\
(0.226)^{* * *}\end{array}$ & $\begin{array}{c}-2.067 \\
(0.169)^{* * *}\end{array}$ & $\begin{array}{c}-2.206 \\
(0.170)^{* * *}\end{array}$ & $\begin{array}{c}-0.663 \\
(0.262)^{* *}\end{array}$ & $\begin{array}{c}-0.703 \\
(0.264)^{* * *}\end{array}$ \\
\hline White & 18714 & $\begin{array}{c}-2.811 \\
(0.0195)^{* * *}\end{array}$ & $\begin{array}{c}-3.164 \\
(0.198)^{* * *}\end{array}$ & $\begin{array}{c}-2.057 \\
(0.161)^{* * *}\end{array}$ & $\begin{array}{c}-2.255 \\
(0.162)^{* * *}\end{array}$ & $\begin{array}{c}-0.739 \\
(0.201)^{* * *}\end{array}$ & $\begin{array}{c}-0.770 \\
(0.202)^{* * *}\end{array}$ \\
\hline Black & 10829 & $\begin{array}{c}-6.396 \\
(0.346)^{* * *}\end{array}$ & $\begin{array}{c}-6.519 \\
(0.349)^{* * *}\end{array}$ & $\begin{array}{c}-3.341 \\
(0.208)^{* * *}\end{array}$ & $\begin{array}{c}-3.391 \\
(0.210)^{* * *}\end{array}$ & $\begin{array}{c}-0.713 \\
(0.410)^{*}\end{array}$ & $\begin{array}{c}-0.794 \\
(0.413)^{*}\end{array}$ \\
\hline Unmarried & 11476 & $\begin{array}{c}-4.302 \\
(0.293)^{* * *}\end{array}$ & $\begin{array}{c}-4.430 \\
(0.295)^{* * *}\end{array}$ & $\begin{array}{c}-2.434 \\
(0.214)^{* * *}\end{array}$ & $\begin{array}{c}-2.480 \\
(0.193)^{* * *}\end{array}$ & $\begin{array}{c}-1.254 \\
(0.412)^{* * *}\end{array}$ & $\begin{array}{c}-1.284 \\
(0.413)^{* * *}\end{array}$ \\
\hline Protestant & 20949 & $\begin{array}{c}-3.883 \\
(0.206)^{* * *}\end{array}$ & $\begin{array}{c}-4.198 \\
(0.209)^{* * *}\end{array}$ & $\begin{array}{c}-2.315 \\
(0.155)^{* * *}\end{array}$ & $\begin{array}{c}-2.482 \\
(0.156)^{* * *}\end{array}$ & $\begin{array}{c}-0.779 \\
(0.239)^{* * *}\end{array}$ & $\begin{array}{c}-0.828 \\
(0.243)^{* * *}\end{array}$ \\
\hline Catholic & 5581 & $\begin{array}{c}-2.489 \\
(0.312)^{* * *}\end{array}$ & $\begin{array}{c}-2.641 \\
(0.314)^{* * *}\end{array}$ & $\begin{array}{c}-1.795 \\
(0.278)^{* * *}\end{array}$ & $\begin{array}{c}-1.887 \\
(0.259)^{* * *}\end{array}$ & $\begin{array}{l}-0.230 \\
(0.358)\end{array}$ & $\begin{array}{l}-0.289 \\
(0.355)\end{array}$ \\
\hline
\end{tabular}

Notes: The effect of $\log ($ after-tax price of giving) on $\log ($ amount of religious contributions +1$)$ is reported. All regressions include a set of control variables, and state and year effects as discussed in the text as presented in Table 1. FE and IV-FE models also control for individual fixed effects but exclude time-invariant covariates such as gender, race, and age. Average marginal effects calculated at $\mathrm{E}[\mathrm{Y} \mid \mathrm{Y}>0, \mathrm{X}$ ) are reported for Tobit and IV-Tobit models. Robust standard errors clustered at the individual level are reported in parentheses. The signs $*, * *$, and $* * *$ indicate that the estimate is statistically significant at 10,5 , and 1 percent significance levels respectively. 
Table 4. The effect of charitable subsidies on religious attendance

\begin{tabular}{|c|c|c|c|c|c|c|c|}
\hline & \multirow[b]{2}{*}{ No. of Obs. } & \multicolumn{3}{|c|}{$\log$} & \multicolumn{3}{|c|}{ Level } \\
\hline & & OLS & Tobit & $\mathrm{FE}$ & OLS & Tobit & $\mathrm{FE}$ \\
\hline Full sample & 31092 & $\begin{array}{c}-0.586 \\
(0.076)^{* * *}\end{array}$ & $\begin{array}{c}-0.505 \\
(0.064)^{* * *}\end{array}$ & $\begin{array}{c}-0.267 \\
(0.072)^{* * *}\end{array}$ & $\begin{array}{c}-0.397 \\
(0.154)^{* * *}\end{array}$ & $\begin{array}{c}-0.423 \\
(0.097)^{* * *}\end{array}$ & $\begin{array}{c}-0.439 \\
(0.166)^{* * *}\end{array}$ \\
\hline Male & 14920 & $\begin{array}{c}-0.589 \\
(0.109)^{* * *}\end{array}$ & $\begin{array}{c}-0.499 \\
(0.091)^{* * *}\end{array}$ & $\begin{array}{c}-0.186 \\
(0.103)^{*}\end{array}$ & $\begin{array}{c}-0.456 \\
(0.220)^{* *}\end{array}$ & $\begin{array}{c}-0.446 \\
(0.137)^{* * *}\end{array}$ & $\begin{array}{c}-0.278 \\
(0.237)\end{array}$ \\
\hline Female & 16172 & $\begin{array}{c}-0.584 \\
(0.107)^{* * *}\end{array}$ & $\begin{array}{c}-0.513 \\
(0.090)^{* * *}\end{array}$ & $\begin{array}{c}-0.345 \\
(0.101)^{* * *}\end{array}$ & $\begin{array}{c}-0.337 \\
(0.217)\end{array}$ & $\begin{array}{c}-0.404 \\
(0.136)^{* * *}\end{array}$ & $\begin{array}{c}-0.587 \\
(0.233)^{* *}\end{array}$ \\
\hline White & 18714 & $\begin{array}{c}-0.585 \\
(0.099)^{* * *}\end{array}$ & $\begin{array}{c}-0.473 \\
(0.081)^{* * *}\end{array}$ & $\begin{array}{c}-0.081 \\
(0.083)\end{array}$ & $\begin{array}{c}-0.477 \\
(0.183)^{* * *}\end{array}$ & $\begin{array}{c}-0.446 \\
(0.116)^{* * *}\end{array}$ & $\begin{array}{c}-0.052 \\
(0.168)\end{array}$ \\
\hline Black & 10829 & $\begin{array}{c}-1.259 \\
(0.122)^{* * *}\end{array}$ & $\begin{array}{c}-1.074 \\
(0.106)^{* * *}\end{array}$ & $\begin{array}{c}-0.827 \\
(0.146)^{* * *}\end{array}$ & $\begin{array}{c}-2.306 \\
(0.335)^{* * *}\end{array}$ & $\begin{array}{c}-1.484 \\
(0.199)^{* * *}\end{array}$ & $\begin{array}{c}-1.819 \\
(0.429)^{* * *}\end{array}$ \\
\hline Unmarried & 11476 & $\begin{array}{c}-1.105 \\
(0.141)^{* * *}\end{array}$ & $\begin{array}{c}-0.862 \\
(0.114)^{* * *}\end{array}$ & $\begin{array}{c}-0.565 \\
(0.182)^{* * *}\end{array}$ & $\begin{array}{c}-1.312 \\
(0.271)^{* * *}\end{array}$ & $\begin{array}{c}-0.961 \\
(0.167)^{* * *}\end{array}$ & $\begin{array}{c}-1.390 \\
(0.346)^{* * *}\end{array}$ \\
\hline Protestant & 20949 & $\begin{array}{c}-0.592 \\
(0.092)^{* * *}\end{array}$ & $\begin{array}{c}-0.538 \\
(0.080)^{* * *}\end{array}$ & $\begin{array}{c}-0.272 \\
(0.088)^{* * *}\end{array}$ & $\begin{array}{c}-0.521 \\
(0.203)^{* * *}\end{array}$ & $\begin{array}{c}-0.510 \\
(0.128)^{* * *}\end{array}$ & $\begin{array}{c}-0.791 \\
(0.223)^{* * *}\end{array}$ \\
\hline Catholic & 5581 & $\begin{array}{c}-0.378 \\
(0.165)^{* *}\end{array}$ & $\begin{array}{c}-0.342 \\
(0.148)^{* *}\end{array}$ & $\begin{array}{l}-0.219 \\
(0.164)\end{array}$ & $\begin{array}{c}0.303 \\
(0.300)\end{array}$ & $\begin{array}{c}0.046 \\
(0.190)\end{array}$ & $\begin{array}{l}-0.516 \\
(0.316)\end{array}$ \\
\hline
\end{tabular}

Notes: The effect of $\log$ (after-tax price of giving) on religious attendance is reported. In the first three columns, the dependent variable is log(average number of days that the respondent reported attending a religious service per month+0.1). In the last three columns the dependent variable is the average number of days that the respondent reported attending a religious service per month. All regressions include a set of control variables, and state and year effects as discussed in the text and as presented in Table 1. FE models also control for individual fixed effects but exclude time-invariant covariates such as gender, race, and age. In the second column, average marginal effects calculated at $\mathrm{E}[\mathrm{Y} \mid \mathrm{Y}>\log (0.1), \mathrm{X})$ are reported for Tobit models. In the fifth column, average marginal effects calculated at $\mathrm{E}[\mathrm{Y} \mid \mathrm{Y}>0, \mathrm{X})$ are reported for Tobit models. Robust standard errors clustered at the individual level are reported in parentheses. The signs *, **, and *** indicate that the estimate is statistically significant at 10, 5, and 1 percent significance levels respectively. 
Table 5. The effect of charitable subsidies on religious attendance: Robustness checks

\begin{tabular}{|c|c|c|c|c|c|c|c|}
\hline & \multirow[b]{2}{*}{ No. of Obs. } & \multicolumn{3}{|c|}{$\log$} & \multicolumn{3}{|c|}{ Level } \\
\hline & & OLS & Tobit & $\mathrm{FE}$ & OLS & Tobit & $\mathrm{FE}$ \\
\hline \multicolumn{8}{|l|}{ Income endogeneity } \\
\hline Predicted income & 31050 & $\begin{array}{c}-1.008 \\
(0.078)^{* * *}\end{array}$ & $\begin{array}{c}-0.850 \\
(0.065)^{* * *}\end{array}$ & $\begin{array}{c}-0.203 \\
(0.074)^{* * *}\end{array}$ & $\begin{array}{c}-1.162 \\
(0.162)^{* * *}\end{array}$ & $\begin{array}{c}-0.940 \\
(0.100)^{* * *}\end{array}$ & $\begin{array}{c}-0.276 \\
(0.153)^{*}\end{array}$ \\
\hline Fixed income & 30479 & $\begin{array}{c}-0.641 \\
(0.078)^{* * *}\end{array}$ & $\begin{array}{c}-0.554 \\
(0.065)^{* * *}\end{array}$ & $\begin{array}{c}-0.195 \\
(0.073)^{* * *}\end{array}$ & $\begin{array}{c}-0.486 \\
(0.162)^{* * *}\end{array}$ & $\begin{array}{c}-0.492 \\
(0.100)^{* * *}\end{array}$ & $\begin{array}{c}-0.325 \\
(0.171)^{*}\end{array}$ \\
\hline \multicolumn{8}{|l|}{ Interaction terms } \\
\hline Income/year interactions & 31092 & $\begin{array}{c}-0.586 \\
(0.076)^{* * *}\end{array}$ & $\begin{array}{c}-0.505 \\
(0.064)^{* * *}\end{array}$ & $\begin{array}{c}-0.270 \\
(0.072)^{* * *}\end{array}$ & $\begin{array}{c}-0.397 \\
(0.154)^{* * *}\end{array}$ & $\begin{array}{c}-0.423 \\
(0.096)^{* * *}\end{array}$ & $\begin{array}{c}-0.442 \\
(0.166)^{* * *}\end{array}$ \\
\hline State/year interactions & 31092 & $\begin{array}{c}-0.585 \\
(0.076)^{* * *}\end{array}$ & $\begin{array}{c}-0.504 \\
(0.064)^{* * *}\end{array}$ & $\begin{array}{c}-0.270 \\
(0.073)^{* * *}\end{array}$ & $\begin{array}{c}-0.394 \\
(0.155)^{* *}\end{array}$ & $\begin{array}{c}-0.421 \\
(0.097)^{* * *}\end{array}$ & $\begin{array}{c}-0.446 \\
(0.166)^{* * *}\end{array}$ \\
\hline Income/state interactions & 31092 & $\begin{array}{c}-0.632 \\
(0.076)^{* * *}\end{array}$ & $\begin{array}{c}-0.527 \\
(0.064)^{* * *}\end{array}$ & $\begin{array}{c}-0.245 \\
(0.073)^{* * *}\end{array}$ & $\begin{array}{c}-0.708 \\
(0.156)^{* * *}\end{array}$ & $\begin{array}{c}-0.498 \\
(0.097)^{* * *}\end{array}$ & $\begin{array}{c}-0.427 \\
(0.166)^{* * *}\end{array}$ \\
\hline
\end{tabular}

Notes: The effect of $\log ($ after-tax price of giving) on religious attendance is reported. In the first three columns, the dependent variable is log(average number of days that the respondent reported attending a religious service per month+0.1). In the last three columns the dependent variable is the average number of days that the respondent reported attending a religious service per month. All regressions include a set of control variables, and state and year effects as discussed in the text and as presented in Table 1. FE models also control for individual fixed effects but exclude time-invariant covariates such as gender, race, and age. In the second column, average marginal effects calculated at $\mathrm{E}[\mathrm{Y} \mid \mathrm{Y}>\log (0.1), \mathrm{X})$ are reported for Tobit models. In the fifth column, average marginal effects calculated at $\mathrm{E}[\mathrm{Y} \mid \mathrm{Y}>0, \mathrm{X})$ are reported for Tobit models. Robust standard errors clustered at the individual level are reported in parentheses. The signs *, $* *$, and $* * *$ indicate that the estimate is statistically significant at 10,5 , and 1 percent significance levels respectively. 
Table 6. The effect of religious giving on religious attendance

\begin{tabular}{|c|c|c|c|c|c|c|c|}
\hline & \multirow[b]{2}{*}{ No. of Obs. } & \multicolumn{3}{|c|}{ Prob. of giving } & \multicolumn{3}{|c|}{ Contribution amount } \\
\hline & & 2SLS & IV-Tobit & IV-FE & 2SLS & IV-Tobit & IV-FE \\
\hline Full sample & 31092 & $\begin{array}{c}1.405 \\
(0.146)^{* * *}\end{array}$ & $\begin{array}{c}1.229 \\
(0.128)^{* * *}\end{array}$ & $\begin{array}{c}2.736 \\
(0.951)^{* * *}\end{array}$ & $\begin{array}{c}0.169 \\
(0.018)^{* * *}\end{array}$ & $\begin{array}{c}0.145 \\
(0.016)^{* * *}\end{array}$ & $\begin{array}{c}0.424 \\
(0.148)^{* * *}\end{array}$ \\
\hline Male & 14920 & $\begin{array}{c}1.381 \\
(0.204)^{* * *}\end{array}$ & $\begin{array}{c}1.186 \\
(0.180)^{* * *}\end{array}$ & $\begin{array}{c}2.034 \\
(1.247)^{*}\end{array}$ & $\begin{array}{c}0.168 \\
(0.025)^{* * *}\end{array}$ & $\begin{array}{c}0.141 \\
(0.022)^{* * *}\end{array}$ & $\begin{array}{c}0.308 \\
(0.189)^{*}\end{array}$ \\
\hline Female & 16172 & $\begin{array}{c}1.426 \\
(0.210)^{* * *}\end{array}$ & $\begin{array}{c}1.275 \\
(0.183)^{* * *}\end{array}$ & $\begin{array}{c}3.338 \\
(1.440)^{* *}\end{array}$ & $\begin{array}{c}0.171 \\
(0.025)^{* * *}\end{array}$ & $\begin{array}{c}0.150 \\
(0.023)^{* * *}\end{array}$ & $\begin{array}{c}0.524 \\
(0.228)^{* *}\end{array}$ \\
\hline White & 18714 & $\begin{array}{c}1.598 \\
(0.205)^{* * *}\end{array}$ & $\begin{array}{c}1.340 \\
(0.181)^{* * *}\end{array}$ & $\begin{array}{l}0.570 \\
(0.566)\end{array}$ & $\begin{array}{c}0.208 \\
(0.027)^{* * *}\end{array}$ & $\begin{array}{c}0.172 \\
(0.024)^{* * *}\end{array}$ & $\begin{array}{c}0.109 \\
(0.109)\end{array}$ \\
\hline Black & 10829 & $\begin{array}{c}1.691 \\
(0.144)^{* * *}\end{array}$ & $\begin{array}{c}1.440 \\
(0.121)^{* * *}\end{array}$ & $\begin{array}{l}11.158 \\
(8.706)\end{array}$ & $\begin{array}{c}0.197 \\
(0.017)^{* * *}\end{array}$ & $\begin{array}{c}0.170 \\
(0.014)^{* * *}\end{array}$ & $\begin{array}{c}1.160 \\
(0.644)^{*}\end{array}$ \\
\hline Unmarried & 11476 & $\begin{array}{c}1.970 \\
(0.192)^{* * *}\end{array}$ & $\begin{array}{c}1.527 \\
(0.158)^{* * *}\end{array}$ & $\begin{array}{c}2.938 \\
(1.120)^{* * *}\end{array}$ & $\begin{array}{c}0.257 \\
(0.025)^{* * *}\end{array}$ & $\begin{array}{c}0.198 \\
(0.021)^{* * *}\end{array}$ & $\begin{array}{c}0.450 \\
(0.174)^{* * *}\end{array}$ \\
\hline Protestant & 20949 & $\begin{array}{c}1.312 \\
(0.167)^{* * *}\end{array}$ & $\begin{array}{c}1.230 \\
(0.148)^{* * *}\end{array}$ & $\begin{array}{c}2.477 \\
(1.014)^{* *}\end{array}$ & $\begin{array}{c}0.152 \\
(0.020)^{* * *}\end{array}$ & $\begin{array}{c}0.141 \\
(0.018)^{* * *}\end{array}$ & $\begin{array}{c}0.349 \\
(0.138)^{* * *}\end{array}$ \\
\hline Catholic & 5581 & $\begin{array}{c}1.214 \\
(0.438)^{* * *}\end{array}$ & $\begin{array}{c}1.103 \\
(0.402)^{* * *}\end{array}$ & $\begin{array}{c}4.638 \\
(5.994)\end{array}$ & $\begin{array}{c}0.152 \\
(0.056)^{* * *}\end{array}$ & $\begin{array}{c}0.135 \\
(0.052)^{* * *}\end{array}$ & $\begin{array}{l}4.638 \\
(5.994)\end{array}$ \\
\hline
\end{tabular}

Notes: The effects of decision to give to a religious organization and $\log ($ amount of religious contributions +1$)$ on $\log ($ average number of days that the respondent reported attending a religious service per month+0.1) are reported. In all models, the instrument is log(after-tax price of giving). All regressions include a set of control variables, and state and year effects as discussed in the text and as presented in Table 1. FE models also control for individual fixed effects but exclude time-invariant covariates such as gender, race, and age. Average marginal effects calculated at $\mathrm{E}[\mathrm{Y} \mid \mathrm{Y}>\log (0.1), \mathrm{X})$ are reported for IV-Tobit models. Robust standard errors clustered at the individual level are reported in parentheses. The signs *, **, and *** indicate that the estimate is statistically significant at 10,5 , and 1 percent significance levels respectively. 


\section{Appendix}

Table A1. Fixed effects estimates of the impact of the after-tax price of giving on religious giving and attendance

\begin{tabular}{|c|c|c|c|c|}
\hline & \multicolumn{2}{|c|}{ Religious giving } & \multicolumn{2}{|c|}{ Religious attendance } \\
\hline & $\begin{array}{l}\text { Prob. of } \\
\text { giving }\end{array}$ & $\begin{array}{c}\text { Contribution } \\
\text { amount }\end{array}$ & $\log$ & Level \\
\hline Price & $\begin{array}{c}-0.098 \\
(0.029)^{* * *}\end{array}$ & $\begin{array}{c}-0.630 \\
(0.186)^{* * *}\end{array}$ & $\begin{array}{c}-0.267 \\
(0.072)^{* * *}\end{array}$ & $\begin{array}{c}-0.439 \\
(0.166)^{* * *}\end{array}$ \\
\hline $\ln$ (income) & $\begin{array}{c}0.032 \\
(0.007)^{* * *}\end{array}$ & $\begin{array}{c}0.226 \\
(0.039)^{* * *}\end{array}$ & $\begin{array}{l}-0.022 \\
(0.020)\end{array}$ & $\begin{array}{l}-0.067 \\
(0.047)\end{array}$ \\
\hline Family size & $\begin{array}{l}-0.002 \\
(0.006)\end{array}$ & $\begin{array}{l}-0.022 \\
(0.038)\end{array}$ & $\begin{array}{c}-0.032 \\
(0.017)^{*}\end{array}$ & $\begin{array}{c}-0.069 \\
(0.033)^{* *}\end{array}$ \\
\hline No. of children & $\begin{array}{c}0.025 \\
(0.008)^{* * *}\end{array}$ & $\begin{array}{c}0.171 \\
(0.050)^{* * *}\end{array}$ & $\begin{array}{c}0.045 \\
(0.022)^{* *}\end{array}$ & $\begin{array}{c}0.222 \\
(0.053)^{* * *}\end{array}$ \\
\hline Employed & $\begin{array}{c}0.010 \\
(0.011)\end{array}$ & $\begin{array}{c}0.050 \\
(0.069)\end{array}$ & $\begin{array}{l}-0.019 \\
(0.030)\end{array}$ & $\begin{array}{c}0.035 \\
(0.077)\end{array}$ \\
\hline Married & $\begin{array}{c}0.040 \\
(0.016)^{* * *}\end{array}$ & $\begin{array}{c}0.242 \\
(0.096)^{* *}\end{array}$ & $\begin{array}{c}0.052 \\
(0.041)\end{array}$ & $\begin{array}{l}-0.109 \\
(0.090)\end{array}$ \\
\hline High school & $\begin{array}{c}0.056 \\
(0.016)^{* * *}\end{array}$ & $\begin{array}{c}0.262 \\
(0.099)^{* * *}\end{array}$ & $\begin{array}{c}-0.639 \\
(0.041)^{* * *}\end{array}$ & $\begin{array}{c}-4.395 \\
(0.097)^{* * *}\end{array}$ \\
\hline College & $\begin{array}{c}-0.171 \\
(0.049)^{* * *}\end{array}$ & $\begin{array}{c}-1.253 \\
(0.294)^{* * *}\end{array}$ & $\begin{array}{c}-0.945 \\
(0.124)^{* * *}\end{array}$ & $\begin{array}{c}-4.524 \\
(0.365)^{* * *}\end{array}$ \\
\hline Graduate & $\begin{array}{c}-0.216 \\
(0.097)^{* *}\end{array}$ & $\begin{array}{c}-1.127 \\
(0.621)^{*}\end{array}$ & $\begin{array}{l}-0.018 \\
(0.328)\end{array}$ & $\begin{array}{l}-1.313 \\
(0.909)\end{array}$ \\
\hline Year $=2005$ & $\begin{array}{c}0.012 \\
(0.004)^{* * *}\end{array}$ & $\begin{array}{c}0.155 \\
(0.023)\end{array}$ & $\begin{array}{l}-0.014 \\
(0.010)\end{array}$ & $\begin{array}{c}0.022 \\
(0.025)\end{array}$ \\
\hline $\mathrm{R}^{2}$ & 0.019 & 0.023 & 0.019 & 0.009 \\
\hline No. of observations & 31092 & 31092 & 31092 & 31092 \\
\hline
\end{tabular}

Notes: All regressions also include state and individual fixed effects as discussed in the text and as presented in Table 1. Robust standard errors clustered at the individual level are reported in parentheses. The signs $*, * *$, and $* * *$ indicate that the estimate is statistically significant at 10,5 , and 1 percent significance levels respectively. 
Table A2. The effect of the first-dollar tax price on the after-tax price of giving: First stage regressions for Tables 2 and 3

\begin{tabular}{lccc}
\hline & No. of Obs. & OLS & FE \\
\hline Full sample & 31092 & 0.987 & 0.988 \\
& & $(0.001)^{* * *}$ & $(0.001)^{* * *}$ \\
Male & 14920 & 0.987 & 0.989 \\
& & $(0.001)^{* * *}$ & $(0.002)^{* * *}$ \\
Female & 16172 & 0.987 & 0.988 \\
& & $(0.001)^{* * *}$ & $(0.002)^{* * *}$ \\
White & 18714 & 0.986 & 0.987 \\
& & $(0.001)^{* * *}$ & $(0.002)^{* * *}$ \\
Black & 10829 & 0.986 & 0.990 \\
& & $(0.001)^{* * *}$ & $(0.002)^{* * *}$ \\
Unmarried & 11476 & 0.991 & 0.993 \\
& & $(0.001)^{* * *}$ & $(0.002)^{* * *}$ \\
Protestant & \multirow{2}{*}{0.984} & 0.992 \\
& 20949 & $(0.001)^{* * *}$ & $(0.002)^{* * *}$ \\
Catholic & & 0.993 & 0.985 \\
& & $(0.001)^{* * *}$ & $(0.002)^{* * *}$ \\
\hline
\end{tabular}

Notes: The coefficients on $\log$ (first-dollar tax price of giving) are reported. The dependent variable is $\log$ (after-tax price of giving). All regressions include a set of control variables, and state and year effects as discussed in the text and as presented in Table 1. FE models also control for individual fixed effects but exclude time-invariant covariates such as gender, race, and age. The sign $* * *$ indicates that the estimate is statistically significant at 1 percent significance level. 